\title{
Toxicity effects of fungicide residues on the wine-producing process
}

\author{
Ricardo C. Calhelha, João V. Andrade, Isabel C. Ferreira, Letícia M. Estevinho* \\ Mountain Research Center, Escola Superior Agrária de Bragança, Campus de Santa Apolónia, Apartado 1172, 5301-854 Bragança, Portugal
}

Received 21 April 2005; received in revised form 21 April 2005; accepted 21 April 2005

Available online 30 September 2005

\begin{abstract}
We report the detection of several fungicide residues (Dichlofluanid, Benomyl, Iprodione, Procymidone and Vinclozolin) in red and white bottled wines from two Portuguese wine-producing zones. Studies were done in order to evaluate the active compound transfer percentage from grapes to the final product along fermentation process. We also investigated their effects in Saccharomyces and non-Saccharomyces yeasts as well as their influence on the physical, chemical and organoleptic wine properties. All the tested fungicides had a negative effect on in vitro yeast growth, with Dichlofluanid and Benomyl being the most toxic. Zygosaccharomyces rouxii and Saccharomyces cerevisiae were the most resistant yeasts while Rhodotorula glutinis was the most susceptible. Microvinification experiments carried out in the presence of fungicides produced wine samples with unaltered physical, chemical and organoleptic properties, though Benomyl, a slight delay in the initiation of fermentation process was observed.
\end{abstract}

(C) 2005 Elsevier Ltd. All rights reserved.

Keywords: Wine; Fungicides; Toxicity; Yeasts; Microvinification; Quality control

\section{Introduction}

'Brunch Rot' of grapes, caused by the fungus Botrytis cinerea, is a significant problem for the world-wine industry. Plasmopara viticola and Unicula necator are also common fungi encountered in viticulture pests. Although chemical fungicides have been used to combat these problems (Griffiths et al., 1998), they can be nonspecific and therefore can act on organisms other than the target fungus, including other naturally occurring beneficial or pathogenic organisms (Ochiai et al., 2002). Because of their chemical nature, they may also be toxic (Radice et al., 1998; Datta and Gopal, 1999; Gray et al., 1999) and non-biodegradable. Chemical residues can build up in the soil (Athiel et al., 1995) and throughout the food chain (Radice et al., 2001). Consumers worldwide are increasingly conscious of the potential environmental and health problems (Rankin et al., 1989; Bruynzeel et al., 1995; Draper et al., 2003) associated

\footnotetext{
*Corresponding author. Tel.: + 351273303342 ; fax: +351273325405 .

E-mail address: leticia@ipb.pt (L.M. Estevinho).
}

with the build-up of toxic chemicals, particularly in food products (Mukherjee et al., 2003; Lopez and Riba, 1999).

Historically, studies on enological microbiology have centered on yeasts belonging to the genus Saccharomyces that are responsible for alcoholic fermentation. However, other yeasts, especially non-Saccharomyces yeasts present in the initial stages of fermentation process, may influence on the final organoleptic properties of the wine (Pretorius et al., 1999). These genera include Kloeckera, Cryptococcus, Torulaspora, Hansieniaspora, Candida, Pichia, Hansenula, Zygosaccharomyces, Metschinikowia, Debaromyces, Issatchenkia and Rhodotorula. Evidence exists that non-Saccharomyces yeasts may influence the unique enological characteristics of each wine-producing zone (Ganga and Martinez, 2004) and the presence of fungicides can affect yeasts metabolic activity.

Studies on individual determination of some pesticides in grape must and wine at residue level have been published (Cabras et al., 1983; López et al., 1989; Cabras et al., 1998; Cabras and Angioni, 2000). Each country has its own allowed maximal residue levels that 
reflect the agricultural practice followed, but fungicides employment should be controlled because of its toxicity effects.

In the present work, fungicide residues were determined in red and white bottled wines for two different Portuguese wine-producing regions. The transfer percentage of each fungicide from grapes to the final product is also presented. In order to determine what impact these fungicides may have on the quality of wine produced, the current study evaluated fungicide residues effects in wine-producing process, particularly the growth of fermentation yeasts. In vitro and in vivo experiments were done to evaluate those effects for several yeasts present in fermentation process and on the physical, chemical and organoleptic properties of the resulting wine.

\section{Material and methods}

\subsection{Materials and reagents}

HPLC apparatus: a VARIAN 9050 model (1994) equipped with a UV-visible system. GC apparatus: a DANI 1000 model Gas chromatograph (2000) equipped with an ECD detector. Orbital shaker incubator: a Stuart Scientific SI50 model (2001). Autoclave: a P Selecta model (2002). UV-vis spectrophotometer: a Varian Cary 50 Scan model (1998).

Fungicides applied in grapes (trademark compounds) were obtained in a local market: Benomyl (Benlate 50\% w/w; DuPont), Dichlofluanid (Euparene $50 \%$ w/w; Bayer), Iprodione (Rovral 50\% w/w; Rhône-Poulenc), Procymidone (Sumisclex 50\% w/w; Zaneca-Agro) and Vinclozolin (Ronilan 50\% w/w; Basf). All other chemicals, including fungicides used in the in vitro assays (analytical standard compounds), were of the highest available quality, and purchased from Merck (Darmstadt, Germany).

\subsection{Chromatographic determination of fungicide residues in grape must or wine samples}

Extraction procedures: The organic solvent $(2 \times 50 \mathrm{ml}$, methylene chloride and petroleum ether for Benomyl and cyclohexane for Dichlofluanid, Iprodione, Procymidone and Vinclozolin) was added to the corresponding sample $(50 \mathrm{ml})$ in a glass screw-capped tube, and the mixture was shaken twice for $30 \mathrm{~min}$. After the phase separation stage, organic layers were collected and evaporated to dryness under reduced pressure $\left(15 \mathrm{mmHg}, \sim 40^{\circ} \mathrm{C}\right)$. The residue was dissolved in $2 \mathrm{ml}$ of methanol.

HPLC determination of Benomyl: The operating conditions were as follows: a $20 \times 0.4 \mathrm{~cm}$ (i.d.), $10 \mu \mathrm{m}$ ODS C18 column; a mixture of $\mathrm{CH}_{3} \mathrm{CN}, \mathrm{H}_{2} \mathrm{O}$ and buffer solution $(40: 45: 15 \% \mathrm{v} / \mathrm{v})$ as mobile phase at a flow-rate of $0.8 \mathrm{ml} / \mathrm{min}$. The buffer solution was prepared mixing two solutions of $\mathrm{Na}_{2} \mathrm{HPO}_{4}$ and $\mathrm{KH}_{2} \mathrm{PO}_{4} 0.067 \mathrm{M}(3: 2 \mathrm{v} / \mathrm{v})$ so that the $\mathrm{pH}$ was $\sim 7$. The wavelength used was $280 \mathrm{~nm}$ according to compound UV spectrum. The analyses were carried out at $25^{\circ} \mathrm{C}$.

GC-ECD determination of Dichlofluanid, Iprodione, Procymidone and Vinclozolin: The final extracts were filtered through a $0.45 \mu \mathrm{m}$ pore size PTFE membrane and analysed by capillary gas chromatography with electron-capture detection (GC-ECD). The capillary column used was a SPB-5 $(30 \mathrm{~m} \times 0.25 \mathrm{~mm}$ i.d., $0.25 \mu \mathrm{m}$ film thickness). The carrier gas (hydrogen) flow rate was kept constant during the run $(1 \mathrm{ml} / \mathrm{min}$, measured at $100^{\circ} \mathrm{C}$ ). The oven temperature program was as follows: initial temperature $100^{\circ} \mathrm{C}$, held for $1 \mathrm{~min} ; 100-180^{\circ} \mathrm{C}$ rate $10^{\circ} \mathrm{C} / \mathrm{min} ; 180-320^{\circ} \mathrm{C}$ rate $3{ }^{\circ} \mathrm{C} /$ min to $320^{\circ} \mathrm{C}$. The temperature of the injection port was $250{ }^{\circ} \mathrm{C}$, while that of the detector was $300{ }^{\circ} \mathrm{C}$. Fungicide detection was done by comparing retention times of compound standard solutions prepared at concentrations between 0.2 and $4 \mathrm{mg} / 1$ in methanol. Fungicide quantification was done by interpolation from the linear calibration graphs obtained in that range.

Chromatographic determination of fungicide residues was done in white and red bottled-wine samples. In order to determine the active compound transfer rate from grapes to wine, fungicides (trademark compounds) were applied 3 weeks before vintage (period recommended) and followed during the fermentation process. The presence of fungicides was evaluated in (i) musts prepared from grapes obtained in the same day, 2 and 15 days after compounds application; (ii) musts prepared from grapes after the vintage; (iii) musts obtained during and at the end of wine fermentation.

\subsection{In vitro fungicide toxicity assays}

Micro-organisms: Saccharomyces cerevisiae ESA1 and Rhodothorula glutinis ESA7, isolated from wine and Zygosaccharomyces rouxii ESA8, isolated from honey were obtained in Microbiology Laboratory of Escola Superior Agrária de Bragança. Candida utilis IGC2578 was obtained from the Portuguese Yeasts Culture Collection (PYCC) of Universidade Nova de Lisboa. Zygosaccharomyces bailii ISA1025, isolated from wine was obtained from the Microbiology Laboratory of Instituto Superior de Agronomia de Lisboa.

Fungicides used in the present study were Benomyl, Dichlofluanid, Iprodione, Procymidone and Vinclozolin (analytical standard compounds). Due to their low solubility in water, all compounds were dissolved in DMSO at concentrations ranging from 2 to $5 \times 10^{-4} \mathrm{~g} / 1$ using several dilutions steps, and were sterilized by filtration. 
A minimal mineral liquid medium with vitamins (Uden, 1967) with $2 \%$ of glucose $(\mathrm{w} / \mathrm{v})$ was used to prepare the inocula after being sterilized in an autoclave $\left(121^{\circ} \mathrm{C}, 20 \mathrm{~min}\right)$. Erlenmeyer flasks $(150 \mathrm{ml})$ with $50 \mathrm{ml}$ of the liquid culture medium were inoculated with the yeast suspension $\left(10^{8} \mathrm{cfu} / \mathrm{ml}\right)$ and each concentration of fungicide to be tested was added. Incubation was carried out for 6 days at $25^{\circ} \mathrm{C}$ in a rotary shaker at $150 \mathrm{rpm}$. The growth of yeast cultures was monitored by measuring optical density at $640 \mathrm{~nm}$ in a spectrophotometer UV-visible. Controls were carried out in the same conditions but in the absence of fungicides and in the presence of only the solvent DMSO. All assays were carried out under aseptic conditions. Tests were performed in duplicate and $X_{\min }$ (fungicide concentration that inhibited $10 \%$ of the yeasts growth) and $X_{\max }$ (fungicide concentration that inhibited $90 \%$ of the yeasts growth) were determined by linear regression analysis and expressed as the mean of the duplicate values.

\subsection{In vivo microvinification assays}

Micro-organisms: S. cerevisiae ESA1; S. cerevisiae MB and MT, isolated from white and red wines respectively, were obtained by Universidade Nova de Lisboa.

Fungicides Benomyl and Dichlofluanid (trademark compounds) were applied in a concentration of $2 \mathrm{mg} / \mathrm{l}$ of must as recommended in the label.

The grapes $(40 \mathrm{Kg})$ were collected to open plastic boxes and then transported to Adega Cooperativa de Murça for microvinification assays. The pressing of grapes was done at $18{ }^{\circ} \mathrm{C}$ and the mixture obtained was transferred to inox fermentation wine vats (25-1 capacity). The sulphurous solution $(60 \mathrm{mg} / \mathrm{l})$, the fungicide $(2 \mathrm{mg} / 1$ of must) and the yeast to be studied were added to each wine vat. During the alcoholic fermentation the mixture was re-pressed three times by day and the temperature and density values were measured. At the end of the process the wine was racked to glass demijohn (10-1 capacity) for the malolactic fermentation. The wine was racked again to glass demijohn (5-1 capacity) and the $\mathrm{pH}$ was corrected with tartaric acid. After clarification and before bottling, several analyses were performed. Physical and chemical analyses were done according to the methods recommended by the Organization Internationale de la Vigne et du Vin; density, temperature, $\mathrm{pH}$, alcoholic grade, volatile acidity, total acidity, total $\mathrm{SO}_{2}$ and free $\mathrm{SO}_{2}$ values were determined. The organoleptic analysis was done by a group of five tasters and three parameters were evaluated in different scales: color, 1-3; aroma; 1-4; taste, 1-6 and global impression, 1-7.

\section{Results and discussion}

\subsection{Chromatographic determination of fungicide residues in grape must or wine samples}

Several red and white bottled wines from the regions of Trás-os-Montes and Entre Douro e Minho were analysed for some of the most common fungicides. From the fungicides detected, Benomyl was the most frequently found while Dichlofluanid was not detected in our analyses. The percentage of the samples in which the presence of fungicides was detectable and the levels detected are presented in Table 1 (red bottled-wines) and Table 2 (white bottled-wines). The bottled wines from Entre Douro e Minho region more frequently had detectable levels of the fungicides.

Table 1

Fungicide residues detected in red wine-bottled samples

\begin{tabular}{|c|c|c|c|c|}
\hline \multirow[t]{4}{*}{ Results } & \multicolumn{4}{|c|}{ Producing region } \\
\hline & \multirow{2}{*}{\multicolumn{2}{|c|}{ 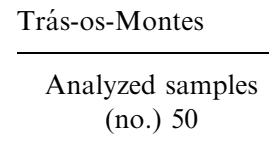 }} & \multirow{2}{*}{\multicolumn{2}{|c|}{ 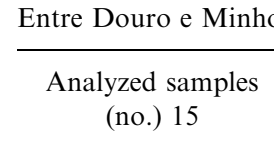 }} \\
\hline & & & & \\
\hline & $a(\%)$ & $b(\mathrm{mg} / \mathrm{l})$ & $a(\%)$ & $b(\mathrm{mg} / \mathrm{l})$ \\
\hline Fungicide & 14 & 0.0175 & 100 & 3.46 \\
\hline Benomyl & 18 & 0.019 & 33 & 0.030 \\
\hline Iprodione & 10 & 0.014 & 67 & 0.072 \\
\hline Procymidone & 0 & $<0.0005$ & 0 & $<0.0005$ \\
\hline $\begin{array}{l}\text { Dichlofluanid } \\
\text { Vinclozolin }\end{array}$ & 14 & 0.015 & 100 & 0.011 \\
\hline
\end{tabular}

(a) Percentage of samples in which was detected the presence of fungicide residues.

(b) Fungicide quantitative levels $(\mathrm{mg} / \mathrm{l})$ detected. The results are expressed as the mean of the analyzed samples.

Table 2

Fungicide residues detected in white wine-bottled samples

\begin{tabular}{|c|c|c|c|c|}
\hline \multirow[t]{4}{*}{ Results } & \multicolumn{4}{|c|}{ Producing region } \\
\hline & \multirow{2}{*}{\multicolumn{2}{|c|}{$\begin{array}{l}\text { Trás-os-Montes } \\
\text { Analyzed samples } \\
\text { (no.) } 15\end{array}$}} & \multirow{2}{*}{\multicolumn{2}{|c|}{$\begin{array}{l}\text { Entre Douro e Minh } \\
\begin{array}{l}\text { Analyzed samples } \\
\text { (no.) } 51\end{array}\end{array}$}} \\
\hline & & & & \\
\hline & $a(\%)$ & $b(\mathrm{mg} / \mathrm{l})$ & $a(\%)$ & $b(\mathrm{mg} / \mathrm{l})$ \\
\hline Fungicide & 27 & 0.127 & 100 & 1.23 \\
\hline Benomyl & 20 & 0.107 & 57 & 0.068 \\
\hline Iprodione & 27 & 0.147 & 39 & 0.0376 \\
\hline Procymidone & 0 & $<0.0005$ & 0 & $<0.0005$ \\
\hline $\begin{array}{l}\text { Dichlofluanid } \\
\text { Vinclozolin }\end{array}$ & 13 & 0.147 & 65 & 0.098 \\
\hline
\end{tabular}

(a) Percentage of samples in which was detected the presence of fungicide residues.

(b) Fungicide quantitative levels $(\mathrm{mg} / \mathrm{l})$ detected. The results are expressed as the mean of the analyzed samples. 
The active compound transfer percentages from grapes to wine are presented in Fig. 1. Benomyl concentration was almost the same in all the process phases. This is consistent with the observation that this compound was the most frequently detected in wine bottled samples $(100 \%$ in wines from Entre Douro e Minho region) (Tables 1 and 2). Dichlofluanid was not detectable after the initial phases of the process. Again this is consistent with the observation that this compound was not also detected in any of the analysed bottled wines (Tables 1 and 2). The percentages of active compound in wine after the fermentation process were $20 \%$ and $30 \%$ for Procymidone and Iprodione, respectively.

\subsection{Evaluation of in vitro fungicide toxicity effects}

The growth of several wine-fermentation yeasts, $S$. cerevisiae, $R$. glutinis, Zygosaccharomyces bailli, $Z$. rouxii and $C$. utilis was evaluated in presence of DMSO fungicide solutions (Iprodione, Procymidone, Dichlo-

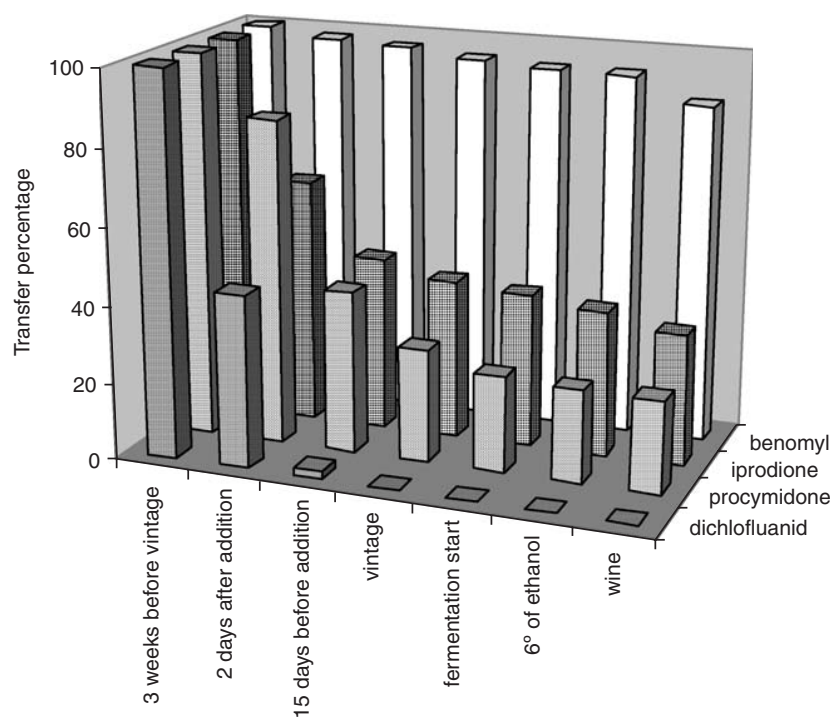

Fig. 1. Active compound transfer percentage along fermentation process. $100 \%$ is correspondent to $1.60 \mathrm{mg} / 1$ for benomyl, $1.69 \mathrm{mg} / 1$ for iprodione, $1.50 \mathrm{mg} / \mathrm{l}$ for procymidone, $1.98 \mathrm{mg} / \mathrm{l}$ for dichlofluanid. fluanid and Benomyl) at different concentrations. DMSO was chosen as solvent after comparative toxicity assays (data not shown) and was not toxic. The results obtained are presented in Table 3.

The presence of fungicides in the culture medium at concentrations above $X_{\min }$ induced the inhibition of yeasts growth. This effect was increased for higher fungicide concentrations. According to the fungicide concentration that inhibited $90 \%$ of the yeasts growth $\left(X_{\max }\right), R$. glutinis was the most susceptible to negative effects of the tested compounds, while $Z$. rouxii and $S$. cerevisiae were more resistant. Dichlofluanid and Benomyl were the most toxic fungicides.

\subsection{Evaluation of in vivo fungicide toxicity effects}

To evaluate the effect of fungicides in the (i) time spent in fermentation start and terminus; (ii) physical and chemical parameters of wine and (iii) organoleptic characteristics of wine, several microvinifications conducted by different $S$. cerevisiae stirpes were performed in the presence and absence of Benomyl and Dichlofluanid. Benomyl was selected because it was most frequently detected by us in bottled wines remaining for a longer time along the process, and presented the higher transfer percentage. Dichlofluanid was chosen because it was the most toxic for the yeasts (see above). The results obtained for the physical and chemical parameters, for the global organoleptic analysis and for the fermentation start and terminus times are presented in Tables 4 and 5 .

Only Benomyl showed a slight delay in the initiation of fermentation, possibly probably due to its toxicity. The physical and chemical parameters did not change with the presence of fungicides. The organoleptic characteristics were also not affected by the presence of those compounds but revealed a dependence on the yeast species used.

On the basis of the above findings, it is concluded that the presence of fungicide active substances showed in vitro negative effects over several yeasts (Saccharomyces and non-Saccharomyces) usually present in the fermentation process, while in the microvinification assays only

Table 3

Fungicide concentration that inhibited $10 \%$ of the yeasts growth $\left(X_{\min }\right)$ and Fungicide concentration that inhibited $90 \%$ of the yeasts growth $\left(X_{\text {máx }}\right)$

\begin{tabular}{|c|c|c|c|c|c|c|c|c|}
\hline \multirow[t]{3}{*}{ Yeast } & \multicolumn{8}{|c|}{ Fungicide solution in DMSO $(\mathrm{g} / \mathrm{l})$} \\
\hline & \multicolumn{2}{|c|}{ Procymidone } & \multicolumn{2}{|c|}{ Benomyl } & \multicolumn{2}{|c|}{ Dichlofluanid } & \multicolumn{2}{|c|}{ Iprodione } \\
\hline & $X_{\min }$ & $X_{\text {máx }}$ & $X_{\min }$ & $X_{\text {máx }}$ & $X_{\min }$ & $X_{\text {máx }}$ & $X_{\min }$ & $X_{\text {máx }}$ \\
\hline S. cerevisiae & 0.15 & 2.00 & 0.10 & 0.75 & 0.0005 & 0.0025 & 0.10 & 1.60 \\
\hline R. glutinis & 0.10 & 0.80 & 0.05 & 0.75 & 0.0005 & 0.002 & 0.10 & 1.25 \\
\hline Z. bailli & 0.15 & 0.80 & 0.05 & 0.75 & 0.0005 & 0.002 & 0.10 & 1.50 \\
\hline C. utilis & 0.15 & 1.60 & 0.02 & 0.25 & 0.0005 & 0.0025 & 0.05 & 1.00 \\
\hline$Z$. rouxii & 0.15 & 2.50 & 0.10 & 0.50 & 0.0005 & 0.0025 & 0.10 & 1.60 \\
\hline
\end{tabular}



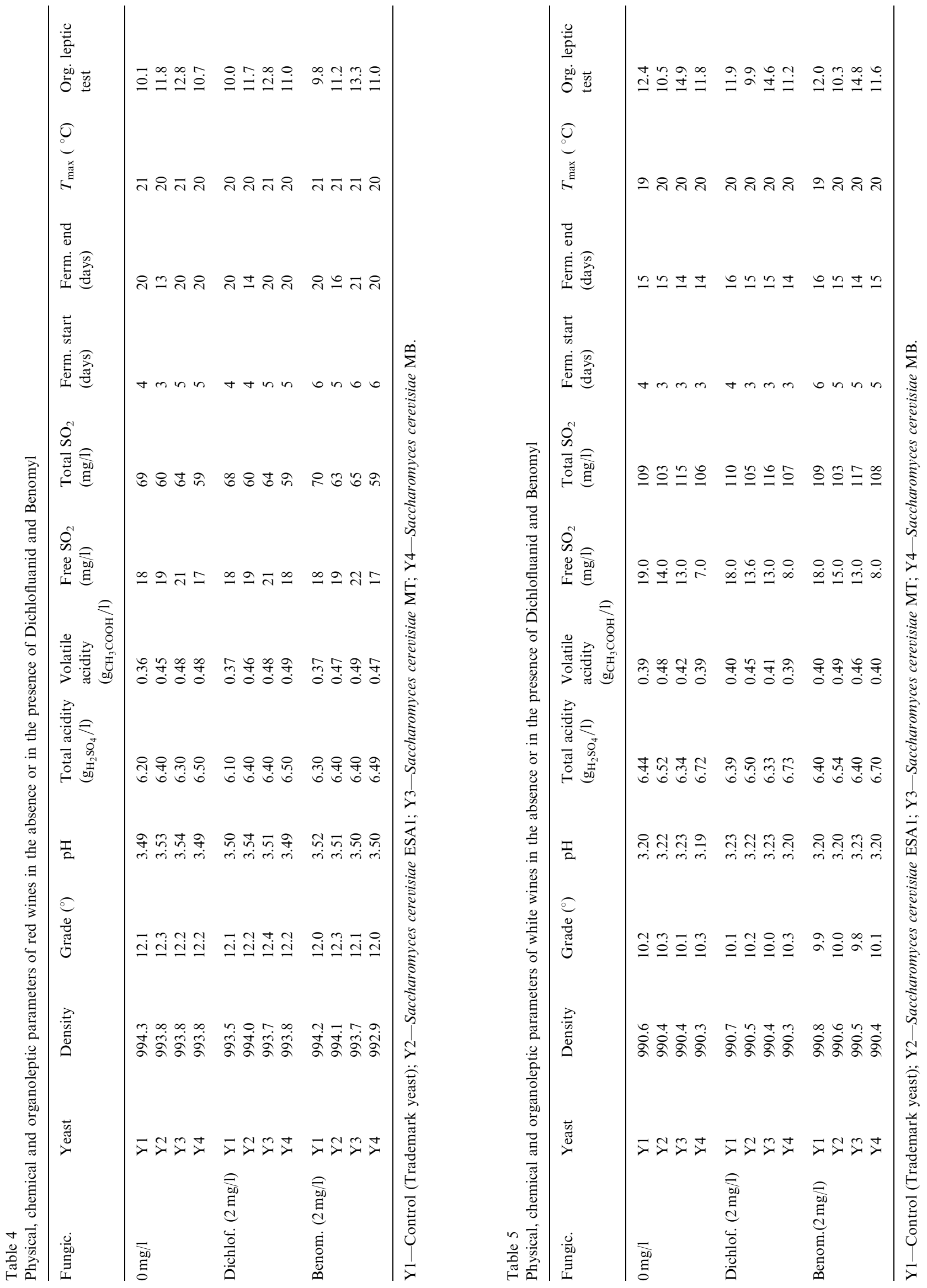
Benomyl showed a delay effect in the fermentation start. The presence of fungicides itself apparently had no influence in the wine characteristics. However, as the levels of fungicides detected in the wine-bottled samples were higher than the admissible (Benomyl and Dichlofluanid- $0 \mathrm{mg} / \mathrm{l}$; Iprodione- $0.01 \mathrm{mg} / \mathrm{l}$; Procymidone$0.005 \mathrm{mg} / 1)$, we recommend the rigorous application of fungicides, both in terms of the recommended dose or the recommended application period.

\section{Acknowledgement}

Thanks are due to PAMAF no. 6088 for financial support.

\section{References}

Athiel, P., Alfizar, Mercadier, C., Vega, D., Bastide, J., Davet, P., Brunel, B., Cleyet-Marel, J.C., 1995. Degradation of iprodione by a soil Arthrobacter-like strain. App. Environ. Microbiol. 61, 3216-3220.

Bruynzeel, D.P., Tafelkruijer, J., Wilks, M.F., 1995. Contact dermatitis due to a new fungicide used in the tulip bulb industry. Contact Dermatitis 33, 8-11.

Cabras, P., Angioni, A., 2000. Pesticide residues in grapes, wine, and their processing products. J. Agric. Food Chem. 48, 967-973.

Cabras, P., Diana, P., Meloni, M., Pirisi, F.M., Pirisi, R., 1983. Reversed-phase high-performance liquid chromatography of pesticides. VII. Analysis of Vinclozolin, Iprodione, Procymidone, Dichlozolinate and their degradation product 3,5-dichloroaniline on white must and wine extracts. J. Chromatogr. 256, 176-181.

Cabras, P., Angioni, A., Garau, V.L., Pirisi, F.M., Brandolini, V., 1998. Gas chromatographic determination of azoxystrobin, fluazinam, kresoxim-methyl, mepanipyrim, and tetraconazole in grapes, must, and wine. J. AOAC Int. 81, 1185-1189.

Datta, A., Gopal, M., 1999. Safety evaluation of the fungicide iprodione on cauliflower (Brassica oleracea var. oleracea L.). Bull. Environ. Contam. Toxicol. 62, 496-501.

Draper, A., Cullinan, P., Jones, M., Newman Taylor, A., 2003. Occupational asthma from fungicides fluazinam and chlorothalonil. Occup. Environ. Med. 60, 76-77.
Ganga, M.A., Martinez, C., 2004. Effect of wine yeast monoculture practice on the biodiversity of non-Saccharomyces yeasts. J. Appl. Microbiol. 96, 76-83.

Gray Jr., L.E., Wolf, C., Lambright, C., Mann, P., Price, M., Cooper, R.L., Ostby, J., 1999. Administration of potentially antiandrogenic pesticides (procymidone, linuron, iprodione, chlozolinate, $p, p^{\prime}$ DDE, and ketoconazole) and toxic substances (dibuthyl- and diethylhexylphtalan PCB 169, and ethane dimethane sulphonate) during sexual differentiation produces diverse profiles of reproductive malformations in the male rat. Toxicol. Ind. Health. 15, 94-118.

Griffiths, R.G., Dancer, J., Harwood, J.L., 1998. The effects of iprodione on the lipid metabolism of Botrytis cinerea. Biochem. Soc. Trans. 26, S155.

Lopez, M.L., Riba, M., 1999. Residue levels of ethoxyquin, imazalil, and iprodione in pears under cold-storage conditions. J. Agric. Food Chem. 47, 3228-3236.

López, L.F., López, A.G., Riba, M.V., 1989. HPLC method for simultaneous determination of fungicides: Carbendazim, Metalaxyl, Folpet, and Propiconazole in must and wine. J. Agric. Food Chem. 37, 684-687.

Mukherjee, I., Gopal, M., Chatterjee, S.C., 2003. Persistence and effectiveness of iprodione against Alternaria blight in mustard. Bull. Environ. Contam. Toxicol. 70, 586-591.

Ochiai, N., Fujimura, M., Oshima, M., Motoyama, T., Ichiishi, A., Yamada-Okabe, H., Yamaguchi, 2002. Effects of iprodione and fludioxonil on glycerol synthesis and hypal development Candida albicans. Biosci. Biotechnol. Biochem. 66, 2209-2215.

Pretorius, I., van der Westhuizen, T., Augustyn, O., 1999. Yeast biodiversity in vineyard and wineries and its importance to the South African wine industry. A review. South African J. Enology Viticulture 20, 61-74.

Radice, S., Marabini, L., Gervasoni, M., Ferraris, M., Chiesara, E., 1998. Adaptation to oxidative stress: effects of vinclozolin and iprodione on the HepG2 cell line. Toxicology 129, 183-191.

Radice, S., Ferraris, M., Marabini, L., Grande, S., Chiesara, E., 2001. Effect of iprodione, a dicarboximide fungicide, on primary cultured rainbow trout (oncorhynchus mykiss) hepatocytes. Aquat. Toxicol. $54,51-58$.

Rankin, G.O., Teets, V.J., Nicoll, D.W., Brown, P.I., 1989. Comparative acute renal effects of three $N$-(3,5-dichlorophenyl)carboximide fungicides: $N$-(3,5-dichlorophenyl)succinimide, vinclozolin and iprodione. Toxicology 56, 263-272.

Uden, V., 1967. Transport limited fermentation and growth of Saccharomyces cerevisiae and its competitive inhibition. Arch. Microbiol. 58, 155-168. 